\title{
Irfani
}

ISSN 1907-0969 E ISSN 2442-8272

Volume 14 Nomor 2 Desember 2018

Halaman 100-106

http://journal.iaingorontalo.ac.id/index.php/ir

\section{PENENTUAN PENGARUH USIA DAN JENIS KELAMIN TERHADAP TINGKAT KECERDASAN (LOGIKA-MATEMATIKA) DENGAN MENGGUNAKAN METODE DISTRIBUSI CHI KUADRAT}

\author{
Suhendra Iskandar \\ Institut Agama Islam Negeri Sultan Amai Gorontalo
}

\begin{abstract}
Abstrak
Telah dilakukan penelitian untuk menentukan pengaruh usia dan jenis kelamin terhadap tingkat kecerdasan (logika-matematika) seseorang. Subjek penelitian diambil dari 32 di antara sekian mahasiswa Jurusan Pendidikan Bahasa Arab Fakultas Tarbiyah dan Ilmu Keguruan IAIN Sultan Amai Gorontalo semester 3 dan 5 tahun ajaran 2016/2017. Ketiga puluh dua subjek penelitian ini dikelompokkan menjadi 2 kelompok usia yakni kelompok usia akhir masa remaja (18-20 tahun) dan kelompok usia awal masa dewasa (21-22 tahun) serta 2 kelompok jenis kelamin yakni kelompok laki-laki dan kelompok perempuan. Setelah itu, subjek-subjek penelitian ini diminta untuk mengerjakan soal essay matematika-statistika-analisis dalam jangka waktu tertentu dengan jumlah soal tertentu dan dengan taraf kesulitan soal yang seragam. Mean dari tiap-tiap kelompok dihitung. Kemudian, melalui data mean dari masing-masing kelompok subjek penelitian ini, dengan menggunakan metode distribusi chi kuadrat, ditentukan bagaimana pengaruh usia dan jenis kelamin terhadap tingkat kecerdasan seseorang. Dari penelitian ini, diperoleh hasil bahwa usia tidak berpengaruh terhadap tingkat kecerdasan seseorang, namun terdapat pengaruh jenis kelamin terhadap tingkat kecerdasan seseorang, di mana kelompok perempuan memiliki tingkat kecerdasan yang lebih tinggi 24,06 \% daripada kelompok laki-laki.
\end{abstract}

Kata kunci: usia, jenis kelamin, tingkat kecerdasan, distribusi chi kuadrat

\section{PENDAHULUAN}

Kecerdasan merupakan salah satu anugerah dari Allah SWT kepada manusia. Kecerdasan ini pulalah yang membedakan manusia dari makhluk lainnya. Dengan adanya kecerdasan, manusia dapat terus mempertahankan dan meningkatkan kualitas hidupnya melalui proses berpikir dan belajar secara terusmenerus selama hidupnya. Menurut Gardner (2003), kecerdasan dibagi menjadi 9, yakni kecerdasan verbal/linguistik, logika-matematika, musik/ritme, visual/spasial, 
gerak/kinestetik, interpersonal, intrapersonal, natural, dan etik/spiritual ${ }^{1}$. Namun, yang akan dikaji lebih lanjut dalam penelitian ini adalah kecerdasan logikamatematika.

Telah banyak opini di masyarakat yang berkembang saat ini bahwa usia dan jenis kelamin menentukan tingkat kecerdasan seseorang. Spearman (1904) dalam Gardner (2003) menyatakan bahwa ada pengaruh antara usia dan tingkat kecerdasan seseorang ${ }^{2}$. Akan tetapi, Sinta (2009) di dalam penelitiannya menyatakan bahwa tidak ada hubungan antara usia terhadap tingkat kecerdasan seseorang, tetapidi dalam penelitiannya, peneliti menggunakan responden yang semuanya berada pada kelompok remaja yang berusia 15-18 tahun ${ }^{3}$. Hakim dkk. (2013) juga menyatakan bahwa tidak ada hubungan antara usia terhadap tingkat kecerdasan seseorang, tetapi di dalam penelitiannya, peneliti menggunakan sampel yang semuanya berada pada kelompok anak-anak yang berusia 6-12 tahun $^{4}$.

Begitupun untuk jenis kelamin, Sinta (2009), Tukijan dan Hartono (2009), serta Susanto dkk. (2014) di dalam penelitiannya menyatakan bahwa ada hubungan antara jenis kelamin terhadap tingkat kecerdasan seseorang ${ }^{5}$. Akan tetapi, Khaterina dan Garliah (2012) ${ }^{6}$ serta Shadiqi dkk (2013) ${ }^{7}$ di dalam penelitiannya menyatakan bahwa tidak ada hubungan antara jenis kelamin terhadap tingkat kecerdasan seseorang.

\footnotetext{
${ }^{1}$ Gardner, H., 2003, Kecerdasan Majemuk: Teori dalam Praktek, diterjemahkan oleh Purwanto, Nuansa, Bandung.

${ }^{2}$ Gardner, H., 2003, Kecerdasan Majemuk: Teori dalam Praktek, diterjemahkan oleh Purwanto, Nuansa, Bandung.

${ }^{3}$ Sinta, A., 2009, Perbedaan Kecerdasan Emosional pada Remaja Pengurus OSIS dengan Reaja Anggota OSIS, Skripsi, Jurusan Psikologi, Fakultas Psikologi Universitas Sumatera Utara, Medan. ${ }^{4}$ Hakim, A.R., Soegiyanto, dan Soekardi, 2013, Pengaruh Usia dan Latihan Keseimbangan terhadap Kemampuan Motorik Kasar Anak Tunagrahita Kelas Bawah Mampu Didik Sekolah Luar Biasa, Journal of Physical Education and Sports 2, 1, 1-5.

${ }^{5}$ Susanto, K., Sasmita, P.K., Desyi, Limantara, A.L., dan Halim, F., 2014, Apakah Jenis Kelamin Berpengaruh terhadap Jenis Kecerdasan Anda, Journal of Medicine, 13(1), 1-8.

${ }^{6}$ Khaterina dan Garliah, L., 2012, Perbedaan Kecerdasan Emosi pada Pria dan Wanita yang Mempelajari dan Yang Tidak Mempelajari Alat Musik Piano, Predicara, 1(1), 17-20.

${ }^{7}$ Shadiqi, M.A., Anward, H.H., Erlyani, N., 2013, Hubungan antara Kecerdasan Emosional dengan Perilaku Pro-Lingkungan serta Perbedaannya Berdasarkan Jenis Kelamin, Ecopsy, 1(1), 15 .
} 
Masih terdapat kesimpang-siuran terhadap kebenaran bahwa usia dan jenis kelamin seseorang menetukan tingkat kecerdasan seseorang akibat masih banyaknya terdapat perbedaan hasil penelitian. Hal inilah yang membuat peneliti tertarik untuk ikut mengaji tentang pengaruh usia dan jenis kelamin terhadap tingkat kecerdasan seseorang.

\section{METODE PENELITIAN}

Penelitian dilakukan dengan menggunakan 32 subjek penelitian yang diambil dari beberapa orang mahasiswa Jurusan Pendidikan Bahasa Arab Fakultas Tarbiyah dan Ilmu Keguruan IAIN Sultan Amai Gorontalo semester 3 dan 5 tahun ajaran 2016/2017 yang memenuhi kriteria yakni memiliki perbedaan usia dan jenis kelamin yang dapat dilihat pada tabel 1. Subjek-subjek penelitian dikelompokkan menjadi kelompok akhir masa remaja (umur 18-20 tahun) dan kelompok awal masa dewasa (umur 21-22 tahun) berdasarkan usia sertakelompok laki-laki dan kelompok perempuan berdasarkan jenis kelamin. Ke-32 subjek penelitian ini diminta untuk mengerjakan soal matematika-statistika-analisis untuk mengukur tingkat kecerdasan logika-matematikanya.Dihitung masing-masing mean dari kelompok-kelompok subjek penelitian kemudian dianalisis data hasil penelitiannya dengan menggunakan metode distribusi chi kuadrat.

Tabel 1. Pengelompokan subjek-subjek penelitian

\begin{tabular}{|c|c|c|}
\hline JK Usia & Akhir Masa Remaja & Awal Masa Dewasa \\
\hline Laki-Laki & 8 orang & 8 orang \\
\hline Perempuan & 8 orang & 8 orang \\
\hline
\end{tabular}

Untuk pengaruh usia terhadap tingkat kecerdasan:

Hipotesis nol : tidak terdapat pengaruh usia terhadap tingkat kecerdasan seseorang.

Hipotesis alternatif 1: terdapat pengaruh usia terhadap tingkat kecerdasan seseorang, di mana kelompok akhir masa remajamemiliki tingkat kecerdasan yang lebih tinggi daripada kelompok awal masa dewasa. 
Hipotesis alternatif 2: terdapat pengaruh usia terhadap tingkat kecerdasan seseorang, di mana kelompok awal masa dewasa memiliki tingkat kecerdasan yang lebih tinggi daripada kelompok akhir masa remaja.

Untuk pengaruh jenis kelamin terhadap tingkat kecerdasan:

Hipotesis nol : tidak terdapat pengaruh jenis kelamin terhadap tingkat kecerdasan seseorang.

Hipotesis alternatif 1: terdapat pengaruh jenis kelamin terhadap tingkat kecerdasan seseorang, di mana kelompok laki-laki memiliki tingkat kecerdasan yang lebih tinggi daripada kelompok perempuan.

Hipotesis alternatif 2: terdapat pengaruh jenis kelamin terhadap tingkat kecerdasan seseorang, di mana kelompok perempuanmemiliki tingkat kecerdasan yang lebih tinggi daripada kelompok laki-laki.

\section{HASIL PENELITIAN DAN PEMBAHASAN}

Selama 90 menit, ke-32 subjek penelitian diminta untuk mengerjakan soal matematika-statistika-analisis yang berjumlah 5 nomor dan dijawab secara essay. Pelaksanaan tes diawasi langsung oleh peneliti, terlebih bahwa ke-32 subjek penelitian adalah mahasiswa yang memiliki latar belakang agama yang baik sehingga kecil kemungkinan akan melanggar amanah atau melakukan tindak kecurangan selama tes sehingga data hasil penelitian dapat terjamin. Setelah memeriksa jawaban hasil tes, hasil tes diberi skor dari 0 (paling buruk) sampai dengan 100 (sempurna), kemudiandihitung nilai mean (rata-rata) dari hasil tes untuk masing-masing kelompok subjek penelitian seperti terlihat pada tabel 2 dan 3.Selanjutnya, hasilnya akan dianalisis dengan menggunakan distribusi chi kuadrat untuk menentukan apakah usia dan jenis kelamin berpengaruh terhadap tingkat kecerdasan seseorang.

Tabel 2. Nilai mean dari hasil tes untuk tiap-tiap kelompok subjek penelitian berdasarkan usia

\begin{tabular}{|c|c|}
\hline Kelompok & Nilai Mean \\
\hline Akhir masa remaja (usia 18-20 tahun) & 25,98 \\
\hline Awal masa dewasa (usia 21-22 tahun) & 32,54 \\
\hline
\end{tabular}




\begin{tabular}{|c|c|}
\hline Keseluruhan & 29,26 \\
\hline
\end{tabular}

Tabel 3. Nilai mean dari hasil tes untuk tiap-tiap kelompok subjek penelitian berdasarkan jenis kelamin

\begin{tabular}{|c|c|}
\hline Kelompok & Nilai Mean \\
\hline Laki-laki & 22,22 \\
\hline Perempuan & 36,30 \\
\hline Keseluruhan & 29,26 \\
\hline
\end{tabular}

\section{A. USIA}

Setelah diperoleh mean dari masing-masing kelompok usia, hasilnya kemudian diolah dengan menggunakan distribusi chi kuadrat seperti yang terlihat pada tabel 4 .

Tabel 4. Distribusi chi kuadrat $\left(\lambda^{2}\right)$ subjek penelitian kelompok usia

\begin{tabular}{|c|c|c|c|c|c|}
\hline Kelompok & $\mathrm{f}_{\mathrm{o}}$ & $\mathrm{f}_{\mathrm{h}}$ & $\mathrm{f}_{\mathrm{o}}-\mathrm{f}_{\mathrm{h}}$ & $\left.\mathrm{f}_{\mathrm{o}}-\mathrm{f}_{\mathrm{h}}\right)^{2}$ & $\lambda^{2}=\frac{\left(f_{o}-f_{h}\right)^{2}}{f_{h}}$ \\
\hline $\begin{array}{c}\text { Akhir masa } \\
\text { remaja } \\
\text { (usia 18-20 } \\
\text { tahun) }\end{array}$ & 25,98 & 29,26 & $-3,28$ & 10,7584 & 3,28 \\
\hline $\begin{array}{c}\text { Awal masa } \\
\text { dewasa } \\
\text { (usia 21-22 } \\
\text { tahun) }\end{array}$ & 32,54 & 29,26 & 3,28 & 10,7584 & 3,28 \\
\hline Jumlah & 58,52 & 58,52 & & & 6,56 \\
\hline
\end{tabular}

Diperoleh hasil bahwa $\lambda^{2}$ hitung sebesar 6,56. Diketahui $\mathrm{dk}=(\mathrm{B}-1)(\mathrm{K}-1)=$ $(2-1)(2-1)=1.1=1$. Adapun $\lambda^{2}$ tabel dengan taraf kesalahan data $1 \%$ untuk dk $=1$ adalah 6,635 (Sugiyono, 2015). $\lambda_{\text {hitung }}^{2}=6,56<\lambda_{\text {tabel }}^{2}(\alpha 1 \%)=6,635$, sehingga $\mathrm{H} 0$ dan Ha1 ditolak dan Ha2 diterima sehingga dapat disimpulkan bahwa tidak terdapat pengaruh usia terhadap tingkat kecerdasan seseorang. 


\section{B. JENIS KELAMIN}

Hal yang sama dilakukan untuk kelompok jenis kelamin. Hasil yang diperoleh kemudian diolah dengan menggunakan distribusi chi kuadrat seperti yang terlihat pada tabel 5 .

Tabel 5. Distribusi chi kuadrat $\left(\lambda^{2}\right)$ subjek penelitian kelompok jenis kelamin

\begin{tabular}{|c|c|c|c|c|c|}
\hline Kelompok & $\mathrm{f}_{\mathrm{o}}$ & $\mathrm{f}_{\mathrm{h}}$ & $\mathrm{f}_{\mathrm{o}}-\mathrm{f}_{\mathrm{h}}$ & ${\left(\mathrm{f}_{\mathrm{o}}-\mathrm{f}_{\mathrm{h}}\right)^{2}}$ & $\frac{\left(f_{o}-f_{h}\right)^{2}}{f_{h}}$ \\
\hline Laki-laki & 22,22 & 29,26 & $-7,04$ & 49,5616 & 7,04 \\
\hline Perempuan & 36,30 & 29,26 & 7,04 & 49,5616 & 7,04 \\
\hline Jumlah & 58,52 & 58,52 & & & 14,08 \\
\hline
\end{tabular}

Diperoleh hasil bahwa $\lambda^{2}$ hitung sebesar 14,08. Diketahuidk $=(B-1)(K-1)=$ $(2-1)(2-1)=1.1=1$. Adapun $\lambda_{\text {tabel }}^{2}$ dengan taraf kesalahan $1 \%$ untuk dk $=$ 1adalah 6,635 (Sugiyono, 2015). $\lambda_{\text {hitung }}^{2}=14,08>\lambda_{\text {tabel }}^{2}(\alpha 1 \%)=6,635$, sehingga H0 ditolak. Berdasarkan data hasil penelitian, diperoleh bahwa perempuan memiliki tingkat kecerdasan 24,06 \% lebih besar daripada laki-laki sehingga Ha1 ditolak dan $\mathrm{Ha} 2$ diterima. Oleh karena itu, dapat disimpulkan bahwa terdapat pengaruh jenis kelamin terhadap tingkat kecerdasan seseorang, di mana kelompok perempuanmemiliki tingkat kecerdasan yang lebih tinggi 24,06 \% daripada kelompok laki-laki.

\section{KESIMPULAN}

Berdasarkan penelitian ini, diperoleh hasil bahwa tidak terdapat pengaruh usia terhadap tingkat kecerdasan seseorang. Adapun jenis kelamin,ternyata mempengaruhi tingkat kecerdasan seseorang, di mana kelompok perempuanmemiliki tingkat kecerdasan yang lebih tinggi 24,06 \% daripada kelompok laki-laki. 


\section{DAFTAR PUSTAKA}

Gardner, H., 2003, Kecerdasan Majemuk: Teori dalam Praktek, diterjemahkan oleh Purwanto, Nuansa, Bandung.

Hakim, A.R., Soegiyanto, dan Soekardi, 2013, Pengaruh Usia dan Latihan Keseimbangan terhadap Kemampuan Motorik Kasar Anak Tunagrahita Kelas Bawah Mampu Didik Sekolah Luar Biasa, Journal of Physical Education and Sports 2, 1, 1-5.

Khaterina dan Garliah, L., 2012, Perbedaan Kecerdasan Emosi pada Pria dan Wanita yang Mempelajari dan Yang Tidak Mempelajari Alat Musik Piano, Predicara, 1(1), 17-20.

Shadiqi, M.A., Anward, H.H., Erlyani, N., 2013, Hubungan antara Kecerdasan Emosional dengan Perilaku Pro-Lingkungan serta Perbedaannya Berdasarkan Jenis Kelamin, Ecopsy, 1(1), 1-5.

Sinta, A., 2009, Perbedaan Kecerdasan Emosional pada Remaja Pengurus OSIS dengan Reaja Anggota OSIS, Skripsi, Jurusan Psikologi, Fakultas Psikologi Universitas Sumatera Utara, Medan.

Sugiono, 2015, Statistika untuk Penelitian, Alfabeta, Bandung.

Susanto, K., Sasmita, P.K., Desyi, Limantara, A.L., dan Halim, F., 2014, Apakah Jenis Kelamin Berpengaruh terhadap Jenis Kecerdasan Anda, Journal of Medicine, 13(1), 1-8.

Tukijan dan Hartono, 2009, Analisis Perbedaan Kecerdasan Emosional, Motivasi Kerja, Kinerja, Ditinjau dari Gender dan Tingkat Pendidikan, makalah disajikan dalam studi faskel ekonomi PNPM mandiri perkotaan Jawa Tengah, tahun 2009, Semarang. 